\title{
Escritor y mundillo literario en la narrativa breve castellana y catalana de finales de milenio: entre el costumbrismo, la intertextualidad y la metaficción
}

\author{
M. ${ }^{a}$ Dolores Madrenas Tinoco y JuAN M. Ribera Llopis \\ C. ${ }^{\circ} .^{r a}$ S. ${ }^{r a}$ del Rosario (Barcelona) - Universidad Complutense de Madrid
}

"iNo volverás a mancharme con la tinta de tus absurdos planteamientos!", dijo el protagonista [...] a su autor. Acto seguido apretó el nudo de la trama a su garganta, dio una patada a la banqueta y se quedó colgado de la primera página como desenlace"l.

"Vivimos un merecido momento de vitalidad del género" 2 . Sirva esta contundente afirmación de José María Merino, uno de los máximos cultivadores de la narrativa breve en la actualidad, para encabezar estas breves palabras introductorias. A falta, aún, de una profunda reflexión teórica y a pesar de no figurar con la relevancia que merece en las historias de la literatura castellanas y catalanas, ni en las de más reciente publicación; con todo, tenemos pruebas fehacientes de que el cuento, en las dos últimas décadas, ha experimentado un auge muy considerable. Ni que sean estudios parciales, contamos ya con especialistas solventes. Dejemos que sea uno de ellos, Fernando Valls, quien esboce un apunte sobre el estado de la cuestión: "En pocos años [...] la situación del cuento ha mejorado: ha salido del encasillamiento en el que se hallaba y empieza a dejar de ser la cenicienta de los géneros literarios clásicos, viéndose favorecido [.... por el abandono de las tendencias experimentalistas, que predominaron durante los últimos sesenta y primeros setenta, y la vuelta al gusto por la narración, la trama y los personajes bien perfilados. Hay autores de varias generaciones que lo cultivan con acierto, editores dispuestos a publicarlos, diarios y revistas que los recogen con asiduidad, y lo más importante: un público interesado en el género"

\footnotetext{
' Óscar Gutiérrez Villarejo, "Subliteratura", Quince líneas, pág. 105.

'El Mundo, 17-X-1998, pág. 15.

${ }^{3}$ F. VALLS, ed., Son cuentos. Antología del relato breve español 1975-1993, Madrid, Espasa Calpe, 1993, (Col. Austral, 326), pág. 53.
} 
La aparición entre los años $80-90$ de antologías de la más variada temática (cuentos de terror, eróticos, fantásticos...), el aluvión de premios y certámenes, contar, incluso, con revistas especializadas - Lucanor-, el número de cultivadores de probada valía en ambas literaturas; ofertas de mercado - factores extraliterarios al margen-, sí, pero también síntomas inequívocos del proceso de normalización del género en todos los niveles apuntados (autores, editores, estudiosos, público...) y de cómo se ha elevado su consideración literaria y social. Tales indicios permiten ser optimistas sin pecar de triunfalismo: es innegable, y más teniendo en cuenta la situación en decenios anteriores, que estamos asistiendo al renacimiento del cuento en España ${ }^{4}$.

Remitimos de nuevo a José María Merino: existe cada vez más una " $c u l$ tura del cuento", una idea de que "elaborar relatos breves no es dedicarse a un género menor, sino afrontar uno de los retos literarios más estimulantes de la escritura de ficciones" $"$. Cuanto menos, ningún crítico ni escritor que se precien pueden seguir sosteniendo hoy en día que el cuento es un simple entretenimiento antes de llevar a cabo empresas de mayor envergadura, como escribir una novela, el mal llamado género mayor.

"De la fantasía sin trabas al reflejo de la vida cotidiana, del ensimismamiento sentimental al horror, de la invención histórica, al gusto metaliterario... todo cabe en los más recientes cuentos. [...] Es esta convivencia de lo clásico y lo moderno el signo relevante de los últimos tiempos. [...] Todas las tendencias, pues, [...] coexisten en el relato breve del último decenio", señala Santos Sanz Villanueva dejando clara la dificultad de precisar las características generales del cuento actual; dada la profusión de cultivadores y tendencias, la diversidad de contenidos, estilos, técnicas y concepciones, quizá "la variedad sea su único rasgo en común", concluye el citado crítico.

Si bien "la autorreflexividad del texto cuentístico" era ya una de las tendencias más marcadas en la década de los 70, según A. Encinar y A. Percival, la "de los 80 marca la aparición de grandes cambios en el campo cultural español producidos bajo la fuerte presión de valores mercantilistas que circulan en un contexto cada vez más cosmopolita, [...] la creciente influencia de los medios de comunicación y reproducción, [...]. Se observan una expansión de las industrias culturales, la burocratización de la cultura, un fuerte consumismo de bienes estéticos, el declive del prestigio del intelectual, y, concretamente, referente al campo literario, [...] una banalización de lo trascendental, y

${ }^{4}$ La propia ficción se hace eco del estado actual del género: "[...] l'auge que darrerament ha aconseguit el gènere. (...J Tots els diaris sense excepció, moltes revistes i fins $i$ tot butlletins corporatius $i$ fulls parroquials, $n$ 'han inclosos entre les seves planes: "Ressucita el conte", "El dijous, un conte". "El conte de mai acabar", etc., són alguns dels títols amb els quals diverses publicacions literàries han encapçalat les planes dedicades a l'entreteniment dels lectors.", C. RIERA, "Això no és un conte", págs. 163-164.

5 "Cien años de cuentos. Un Siglo de Oro para el relato español (1898-1998)", Leer, n. ${ }^{\circ} 96$, octubre 1998, pág. 25 .

6 "El cuento de ayer a hoy", Lucanor, 6, págs. 24-25. 
una atracción por lo light, el hedonismo y el eclecticismo, tachados como síntomas de la posmodernidad [...]"?.

Concluyendo, en la narrativa breve actual se hace literatura de (sobre) la vida y también literatura de (sobre) la literatura. Por ahí decidimos adentrarnos a la hora de fijar unos obligados límites temáticos, previa acotación del marco cronológico - años 80 y 90-, ante tal heterogeneidad de contenidos. Fruto de la propia experiencia lectora, rastreando la producción de un buen número de cuentistas representativos, pudimos constatar la presencia reiterada de relatos metafictivos y sobre todo cuanto concierne al mundo de la literatura. Que el escritor reflexione acerca de los entresijos de su oficio y lo que su práctica comporta, sobre el porqué de explicar historias; es decir, sobre la ficción a través de la ficción, no podemos pretender que resulte novedoso a estas alturas, pero sorprende la asiduidad con que se tratan actualmente dichas cuestiones. ¿A qué viene tal cantidad de relatos que giran en torno a estos temas, abordándolos con inusitada frecuencia en clave de humor, añadiríamos? ¿Tiene alguna relación - como apuntan ciertos críticos- con esta tendencia tan finisecular de valorar más el "proceso" que el "producto", evidenciando así el sentido artificioso y lúdico de la creación literaria? ¿Se trata de plantear un reto al lector al hacerle asistir y/o tomar parte en el proceso creador? ¿Simple divertimento o marca de época?

Convengamos de antemano que aquí emplearemos el concepto metaficción - sin entrar en cuestiones de matiz ni recurrir a la terminología diferenciadora al uso- en el sentido más amplio: cuento que ostenta su condición de artificio, ficción de-en la ficción. Por lo que respecta a los criterios de selección, dada la coexistencia de varias promociones de escritores en plena actividad, y de cara a que nuestro corpus resultara representativo, hemos optado por ofrecer una muestra considerablemente amplia de autores, fueran consagrados o de las últimas hornadas, procurando no repetir nombres ni títulos, salvo considerarlo oportuno. Nos queda señalar por último que, aun cuando sería de sumo interés adentrarnos también en cuetiones de índole estilística para completar el análisis de esta suerte de relatos - se advierte, de entrada, el uso de un lenguaje más bien plano sin que podamos llegar a generalizarlo-, hemos decidido por nuestra parte dejar al margen todo lo que no sean aspectos meramente argumentales.

Si bien el protagonista de los cuentos que dejan al descubierto su condición de artificio suele ser un escritor - con sus variantes: aspirante a escritor, narrador fracasado, autor famoso...- 0 , cuanto menos, un personaje con veleidades literarias, en tiempos de lamentable confusión entre literatura y marketing como

${ }^{7}$ Cuento español contemporáneo (ed. A.EnCinar y A. PerCival), Madrid, Cátedra, 1994, 3. " ed., págs. 32-33.

${ }^{8}$ Gonzalo Sobejano, "La novela ensimismada (1980-1985)", España Contemporánea, Tomo I, n. ${ }^{\circ}$, Invierno 1988, pág. 11. Cabría destacar aquí, a tenor de la bibliografía existente, que lo metafictivo ha despertado más interés por parte de la crítica en el ámbito de la novela que en el del relato breve. 
los nuestros es lógico que tropezamos en las páginas de los relatos con editores, periodistas, traductores, guionistas, críticos... quienes, sin escamotear datos reales de su experiencia cotidiana, nos ofrecen una visión testimonial del actual mundillo literario. Reproducción costumbrista de ciertos usos y hábitos sociales, producto de una sociedad mercantilista y tecnificada en que todo lo rigen las cifras y los índices de ventas, en cuya vorágine se ve envuelto el escritor.

Aunque este tipo de relatos no estén exentos de un cierto propósito de denuncia contra la nefasta incidencia de fenómenos extraliterarios en el ámbito de lo literario, hay que decir que, en la mayoría de ellos - como demuestran los seleccionados-, priva el tono jocoso y desenfadado; son pocas las ocasiones en que el autor emplea el tono trascendente que, tal vez, cabría esperar al tratar asuntos de esta índole. La narrativa breve hoy en día —quizá más la catalana que la castellana, precisaríamos- opta a menudo por recrear el mundo del escritor y de la literatura con un sentido lúdico. Narrativa que se quiere ligera, intrascendente - postmoderna, podríamos decir-, en la que el realismo convencional queda distorsionado mediante el uso de la ironía, el humor, incluso la parodia, ingredientes que mitigan también el propósito crítico. Dejaremos que sean los propios relatos, detenidamente escogidos de acuerdo con los dos centros de interés señalados en el título, los que den buena cuenta de lo dicho.

\section{ESCRITOR}

Atraído por el "talento creador" que cree adivinar en sus relatos y por la capacidad con que describe "los más sutiles y recónditos sentimientos" (pág. 48), el narrador del cuento de Juan Eduardo Zúñiga, "La esposa", decide conocer personalmente al autor y va a visitarle en sucesivas ocasiones. Pero el escritor resulta un ser tosco, poco sociable y menos hablador, a quien envuelve, eso sí, un cierto halo de misterio. Muy a tono con ello, Zúñiga resuelve el relato haciendo aparecer en escena a esa mujer que "fue el personaje único de sus relatos", aunque sabemos, al final, que "hacía muchos años ésta había muerto." (pág. 54)

Cuando estaba empezando una novela de amor, en la que se proponía describir las pasiones más exaltadas, el escritor-fictivo de otro relato de Zúñiga, recibía cada día la visita de su amiga mientras él, "inclinado sobre la mesa cubierta de hojas escritas. [...] se olvidaba de la presencia de ella , [...]. Incluso llegaba a pronunciar en voz alta exclamaciones del amor más arrebatado o promesas de fidelidad eterna, pero no las dirigía a la joven que tenía ante él." (pág. 135). En pocas semanas dicha joven contrae una grave enfermedad y muere, sin que ello le cause efecto alguno, obsesionado como estaba en terminar su obra. Será su pericia para describir sentimientos que es incapaz de experimentar lo que dará pie a "La venganza", precisamente el título del cuento. Una mañana en que se disponía a releer el manuscrito ya finalizado para darle 
los últimos toques: "Enseguida le extrañaron grandes espacios blancos: [...] Donde puso frases de acendrados sentimientos, de fervor y entrega incondicional, de éxtasis amoroso, no había nada. Las palabras se habían esfumado como borradas por una mano que no aceptase el lenguaje de los enamorados." (págs. 136-137). Buscando una explicación a tan extraño fenómeno, el protagonista se acuerda de pronto de su "olvidada amante" (pág. 137), y se arrepiente de "no haberle dado a ella más afecto que a sus escritos." (pág. 138). Presencia fantasmagórica de la amada incluida en el texto que leemos, el cuento tiene un final feliz: el escritor va cubriendo los espacios blancos, a medida que murmura frases de amor, antes destinadas a los personajes de su obra, ahora "dedicadas a la intangible amante que presidía y suscitaba sus pensamientos." (pág. 139).

La aureola de misterio, el autor encerrado en su mundo viviendo al margen de lo que le rodea, tocado, incluso, de cierto malditismo o de un halo de genialidad, necesitando estímulos artificiales para crear - "la inacabable novela [...]; me abrasa entre los dedos [...]; [...].Me apaciguaría un vivo vaso de coñac. El alcohol: único equilibrio viable. [...] Para abrumarme más. [...] Sólo es posible el camino de la destrucción [...]" (pág. 145), en "Hoy, como todos los días"- son algunos de los tópicos que se han ido gestando a lo largo de los tiempos entorno a su figura que, moldeada en estos términos, hoy en día se nos antoja un tanto decimonónica. Pese a que lo de la aureola mítica aún suscite interés, —podríamos aportar más ejemplos a raíz del rastreo de cuentos con protagonista-escritor-, es muy otra la imagen que se suele ofrecer del escritor actualmente, fiel trasunto, como es obvio, de la realidad de nuestros días; lo iremos viendo a través de los textos seleccionados. ¿Sería simplificar demasiado decir que, frente al escritor, llamémosle vocacional, de antaño —el que escribe por mero placer-, en la actualidad lo que más abunda es el escritor profesional -el que lo hace, sobre todo, por dinero-. Quizá no debamos ser tan taxativos al respecto, pero es un hecho constatable que, en la línea de la propensión de la narrativa actual a preferir antihéroes como protagonistas, también la figura del escritor ha sido desacralizada.

Casimiro Porras Rebollo, protagonista del relato de Javier García Sánchez, "Crítica de la Razón Impura", encarna a un presunto escritor vocacional, carente de la más mínima capacidad creativa pero con pretensiones de gran artista. Convencido de que con ese nombre y apellidos y por ser de provincias - según él, para triunfar debería ser de Madrid o de Barcelona-, no podría convertirse jamás en un escritor de prestigio dentro del panorama narrativo español, "Ejercía de escritor frustrado" (pág. 9). Lo cierto es que, en quince años, no había sido capaz de pergeñar más que párrafos o notas sueltas de lo que tenía que ser su ansiada novela, que "creía [...] podía ser fundamental" (pág. 12). Otro tanto le ocurre a la protagonista del relato de Laura Freixas, "La intérprete", quien nos confiesa que lleva "una vida [...] normalísima. Tengo un trabajo, un piso, amigos, algún amante, voy al cine los sábados... Voy a cumplir treinta y dos años; nunca me ha ocurrido nada digno de contarse [...] y no tengo motivos para suponer que me ocurrirá en el futuro. Una vida, en fin, como la de todo 
el mundo...", pero sólo "en apariencia", porque "en verdad, [...] hay una diferencia crucial: soy escritora". Y aunque "no he escrito nada todavía; [...] algún día, estoy segura, escribiré una gran novela." (pág. 24).

Xavier Moret, por su parte, hace que Clàudia, la pareja del protagonistaescritor de su cuento "Es gasten els llapis quan se'n va la llum?", se enamore de él porque: "L'enlluernava sortir amb algú que tenia llibres publicats, freqüentava els ambients culturals, firmava autògrafs.."; es decir, por lo que pueda tener el oficio de proyección social, como el mismo protagonista reconoce. Pero pronto se desilusiona y se produce la ruptura, "amb el temps havia descobert, amb un cert desencant, això sí, que un escriptor no és gaire diferent de la resta dels humans i que, tan bon punt travessa la porta de casa, el glamour s'esvaeix per deixar pas a hores $i$ hores de feina callada, de dedicació a l'escriptura." (pág. 149).

¿Se requiere algún don especial para ser escritor? Eso piensa Josep Maria Pallarols, protagonista de "L'autor plagiat", de quien nos dice el narrador que posee "allò que en diuen el do de la originalitat" (pág. 11), por lo que decide dedicarse a la literatura. Empieza su andadura seleccionando una buena idea y explicando a todo el mundo el argumento por extenso. Alguien se le adelantó $\mathrm{y}$ "va publicar la història en forma de novel la en una editorial de força anomenada."(pág. 12). La emprende con otra sin revelar su contenido a nadie pero, cuál no sería su sorpresa al descubrir que, el último premio de moda, "responia en línies generals al seu mateix esquema i que recollia una anècdota històrica idèntica, [...]" (pág. 12). El manuscrito de su tercera novela es rechazado por el paralelismo innegable de la historia imaginada por él y la escrita por un tal Manuel Oliveres cincuenta años antes.

Unos cuantos guiños de complicidad del narrador para con el lector delatan el tono de este cuento de Jordi Viader: embargaba tal angustia al "nostre protagonista" que "Fins i tot va anar a parlar amb un vident perquè el posés en contacte amb el difunt Oliveres, però no va ser possible per un problema de freqüències." (pág. 14). Su siguiente tentativa está rodeada de toda suerte de medidas de seguridad, no ve a nadie, no habla con nadie, se impone, incluso, no pensar en el argumento de su libro salvo cuando trabaja en él, "No fos cas - es deia-que anant jo pel carrer, rumiant-hi, alguna ment sensible pesqués les meves idees i se n'aprofités." (pág. 15), ni aún así consigue publicar un libro antes de que se le adelanten. Quiere la suerte que el manuscrito sin copia de su última obra lo deje olvidado en el taxi cuando se dirigía a la editorial.

La ambición de cualquier escritor es profesionalizarse, pero no siempre le resulta factible. Hasta llegar a convertirse en un escritor consagrado, si es que lo consigue, y poder vivir de la literatura, suele compaginarla con otros trabajos: traducciones, reseñas, solapas, guiones, artículos periodísticos de todo tipo...; el anteriormente citado Casimiro Porras Rebollo, pongamos por caso, acabará como redactor de la sección deportiva de un períodico local, asumiendo que "la gente puede pasar perfectamente sin literatura, pero no sin fútbol"(pág. 61). Si llega a ser una pluma reconocida, no siempre de acuerdo con 
su verdadera valía, deberá vender su imagen para vender su obra, haciendo bolos, presentándose a concursos, interviniendo en actos oficiales, participando en tertulias radiofónicas y televisivas...

Tanto el escritor real como el fictivo pueden convertir en materia literaria experiencias personales; que el escritor narre en sus obras hechos concretos de su propia vida que le sucederán a posteriori es sólo prerrogativa del escritorfictivo. Le ocurre al protagonista del cuento titulado "La literatura" de Quim Monzó: al releer todas sus novelas con motivo de su próxima reedición, "Veu la seva vida, sencera, predita, llibre a llibre." (pág. 97). Un temor le acecha, en la última novela que ha publicado el protagonista muere y "és evident que encara no han passat prou mesos perquè el que hi ha escrit es faci realitat." (pág. 98). El cuento deja al lector con la misma duda, es literatura.

Aunque no tiene porqué darse un fiel trasunto entre vida y literatura, ni en la vida ni en la literatura, valga la redundancia. Bajo el seudónimo de Albert Sinclair se esconde la personalidad de Concepción Huerta —en "El señor Link visita a un autor" de Paloma Díaz-Mas-, una joven ataviada de esta guisa "camisa de rayas, falda de flores, chaqueta de cuadros, medias gruesas de lana, zapatillas de andar por casa con pompones azul celeste." (pág. 50), en consonancia con la decoración de la casa oscura y maloliente en la que vive en precarias condiciones. De ahí la sorpresa de su editor al ir a visitarla y comprobar, al contrario de lo presumible, que el manuscrito que le entrega"es perfecto, límpido, armonioso, lleno de ritmo y de vida. Es pura música, como un caudal que surge de claros ojos de agua." (págs. 53-54).

\section{I.1. FicCionalización DEl PROCESO CREAdOR}

Consecuencia lógica de que el autor decida que su cuento lo protagonice un escritor es que permita al lector desvelar los secretos del oficio como parte de la trama. Son muchos los relatos en los que asistimos, con más o menos detalle, a todas las fases del proceso creador por las que discurre el quehacer literario del protagonista: trucos, dificultades, tentativas, vacilaciones, problemas formales...; en ellos se abandona la imitación de una realidad extraficcional para centrar la atención en el proceso mismo que crea la obra de ficción.

¿Cómo discurren esas horas interminables delante de una papel o la pantalla en blanco a la espera del argumento? ¿Existe la inspiración? ¿Qué siente el escritor a la hora de escribir? ¿Cuáles son las etapas previas: toma notas, ensaya voces, vislumbra acciones...? A éstas o a similares preguntas suele tener que responder el escritor a menudo. Así nos lo refiere el autor-fictivo, en un relato de Màrius Serra,'Incert so", sin persona interpuesta:

"Una mesura profilàctica, aquesta d'aprendre apunts, [...]. O sigui que, assegut a la taula de l'estudi, vaig llistar tots els elements interessants de l'episodi en un bloc [...]. 
En arribar a aquest punt vaig rellegir el [...] que acabava d'escriure $i$ vaig notar un tènue pessigolleig a les cervicals, símptoma inequivoc que amb els anys he après a relacionar amb les ganes d'escriure." (págs. 32-33)

"En aquella època tenia serioses dificultats per fer parlar en català els personatges de les novel.les que començava a escriure. [...] Fart d'estavellar-me contra les seves llengües aspres provava de concentrar-me en les seves ments $i$ escrivia llargues tirallongues d'allò que els teòrics han convingut a anomenar monòleg interior. Però aviat ho deixava estar. Tornava al narrador que mira amb ulls de saber-ho tot fins que també me'n fastiguejava. $O$ em sentia prou ardit per assajar noves fórmules d'escriptura automàtica, teclejant tota mena d'associacions verbals al teclat de l'ordinador amb els ulls tancats.[...]. I així anava passant l'estona, amb l'escriptura embossada pels jocs d'artifici i una angoixa creixent que només apaivagaven algunes lectures." (pág. 34).

Veamos este otro ejemplo, detallado paso a paso por el escritor-fictivo de "Los temores ocultos" de Luis Mateo Díez, de cómo se va fraguando la trama, al tiempo que da cuenta del resultado del proceso de creación que está llevando a cabo al insertar en el relato que leemos párrafos de lo que dice estar escribiendo:

"Mi imaginación volvía lentamente sobre el centro más incisivo de la trama: $[\ldots]$

"Era necesario someter al personaje a una serie de variaciones psicológicas que acrecentaran su excitación y le fueran llevando al terror.

Me parecía importante intentar una descripción ambiental lo más exhaustiva, [...]. Escribi muy despacio una primera frase: "La noche cerró su vientre en la encrucijada."

$[\ldots]$

No me gustaba ese comienzo. Taché la frase con un rasgo nervioso.

"La noche se apoderaba del barrio como un manto que se cierne cobijando los temores ocultos."

Releí esta nueva frase. Dejé el bolígrafo sobre la mesa y limpié los ojos." (pág. 77).

En ocasiones, el argumento, los personajes o el relato en sí escapan a los designios del autor: "Es un relato absurdo", pensó, sabiéndose avasallado por aquella historia que buscaba desarrollarse sin coincidir plenamente con su voluntad." (pág. 24), reconoce el protagonista de "El viajero perdido" de José María Merino. Otras veces el autor-fictivo admite su condición de demiurgo: "I... J yo soy consciente de mis poderes, enumero las posibilidades de acuerdo a mi imaginación y elijo lo que creo más conveniente. [...], y su poder de someterlos a su voluntad: "Puedo hacerle una visita a Rosaura, quedarme esta 
noche en su apartamento y parodiar algunos juegos eróticos mientras que tú, querido Robert, te mueres de miedo [...], incapaz de encontrar una salida." (pág. 79), leemos en el ya citado cuento "Los temores ocultos".

Al igual que los escritores reales, el autor-fictivo puede atravesar períodos más o menos largos de esterilidad creativa y superarlos: "[...] conectó el ordenador, puso el disco de las ficciones y comenzó a escribir. Al fin, después de tanto tiempo, tenía una idea. Se encontraba enardecido, casi dichoso, con la cabeza clara.

[...] Después de trabajar casi una hora, imprimió lo redactado y regresó a la sala [...]. Se sentía muy bien, pues estaba escribiendo otra vez." (pág. 11), "El viajero perdido".

Abordar el proceso creador no exige, necesariamente, hacerlo en sentido trascendente, ya lo hemos apuntado antes; hay autores que se inclinan por darle al tema un enfoque desenfado, en clave de humor. A tal efecto suelen recurrir a una voz omnisciente y un tanto burlona, como la que narra el relato de Quim Monzó titulado, precisamente, "El conte":

"A mitja tarda l'home s'asseu a l'escriptori, agafa un full de paper en blanc, el fica a la màquina $i$ comença a escriure. La frase inicial li surt de seguida. La segona també. Entre la segona $i$ la tercera dubta uns segons.

Omple una pàgina, treu el full del carro de la màquina i el deixa a un costat, amb la cara en blanc a dalt. A aquest primer full n'hi afegeix un altre, $i$ després un altre. De tant en tant rellegeix el que escriu, ratlla paraules, en canvia l'ordre dins de les frases, elimina paràgrafs, llença fulls sencers a la papera. De cop, enretira la màquina, agafa tot el munt de fulls escrits, el gira del dret $i$ amb un boligraf ratlla, canvia, afegeix, suprimeix. Col.loca el munt de fulls corregits a la dreta, torna a acostar-se a la màquina i reescriu la història de dalt a baix. [...] A nit ja entrada ho rellegeix per enèsima vegada. És un conte. Li agrada molt. [...] Potser és el millor conte que mai hagi escrit. El troba gairebé perfecte." (págs. 167-168).

Sólo le falta el título para ser perfecto del todo. Por mucho que piensa, no se le ocurre "cap títol prou perfecte per aquell conte tan perfecte", (pág. 168) Finalmente, el escritor se da por vencido y decide hacerlo pedazos.

Muy otra es la opinión que tiene de lo que está escribiendo el protagonista del cuento que Emilio Sánchez-Ortiz titula con acierto "Un apunte", su texto narrativo es un incesante discurrir de dudas y divagaciones mientras intenta escribir el relato: "Puede empezar con una descripción asi:: ", dice y sigue la descripción; después, "Arreglo, pulo, añado algún detalle hondo, [...]", señala. "Resulta un poco cruel lo de "una cosa profiere...", pero así salió y así se queda. Si sigo frenándome con tales sandeces no llegaré a escribir nada correcto nunca" (pág. 191), decide. No le acaba de convencer lo que está escribiendo: "La idea resulta un tanto frívola y agarrada por los pelos. El relato no 
es como para desecharlo, pero [...] Por ahora, está incompleto y mudo. No parece fácil sacar partido". Pone de manifiesto su falta de inspiración: "Todos los días igual historia. Cientos de páginas emborronadas para la voraz papelera del fracaso. No estoy en vena." (pág. 196). Y se cuestiona, incluso, su valía:" Escribir no es tarea fácil. Ni siquiera escribir algo malo, rematada y asquerosamente malo e incompleto. [... J Sobre todo cuando se carece de talento..." (pág. 197).

Excepcionalmente, el protagonista del "Relato de noche" de Luis Fernández Roces no es escritor de oficio sino fontanero con aficiones literarias. Miembro de una tertulia cuyos componentes se retan a escribir un cuento cada mes, debe escribir el suyo en una noche; las dudas le asaltan, la inspiración le falla; le queda, ficcionalizar su propia situación: "[...] $]_{i} A$ qué altura de los hechos será mejor iniciarlo? Tampoco he decidido en qué boca ponerlo. [...].

Debo escribir algo, lo que sea, por más que no me guste. Sé que después habrá que rehacerlo, pero el caso, ahora, es dar con un principio. Y no se me ocurre sino hablar de la amargura de un humilde escritor que no alcanza por más que cavila a poner en claro sus ideas." (págs. 324-325).

Puede darse incluso que, en un mismo relato, confluyan dos experiencias creadoras tan opuestas como las de la protagonista y el narrador, respectivamente, del cuento de Cristina Férnández Cubas, "En el hemisferio sur":" $A$ menudo, cuando escribo, me embarga una sensación difícil de definir. Tecleo a una velocidad asombrosa, me olvido de comer y de dormir, el mundo desaparece de mi vista y sólo quedamos yo, el papel el sonido de la máquina..." (pág. 132), explica con vehemencia Clara; en cambio el narrador reconoce "angustiado", "Jamás había conocido ese momento mágico en que el escritor, poseído por una fuerza milagrosa, se ve compelido a rellenar sin descanso hojas y más hojas, a no concederse tregua, a enfermar, a plasmar sobre el papel los dictados de su mente enfebrecida. Pero sabia que eso les ocurría a otros. Había probado a embriagarme, a euforizarme, a relajarme. [...] Pero el papel en blanco seguía ahí. Impertérrito, amenazante, lanzándome su perpetuo desafío, [...]: "Anda, atrévete. Estoy aquí. Hunde en mi cuerpo esas maravillosas palabras que me harán daño. Decídete de una vez. ¿Dónde está esa famosa novela que bulle en tu cerebro? No prives al mundo de tu genio creador." (págs. 134-135).

Por su parte, a la hora de ponerse a escribir, la protagonista de "Deu paràgrafs" de Sergi Pàmies tiene claro el tema "un conte sobre una dona que cus un botó" (pág. 59), el problema estriba en hacérselo verosímil al lector, "Explicar que, sense adonar-se'n, algú acaba cosint-se diferents parts del cos no és fàcil, opina. És conscient que, per tal que el lector s'ho arribi a creure, cal justificar-ho, encara que sigui amb una raó fantàstica, com ara que la dona està distreta pensant en una altra cosa i això fa que cusi mecànicament, sense fixar$s$ 'hi." (pág. 61). La escritora-fictiva alterna la relectura de lo que va escribiendo - se insertan fragmentos del cuento en gestación en el que estamos leyendo-, las correcciones y recapitulaciones con vasos de vino, según acostumbra (un tópico también muy manido asociar alcohol con literatura). Llega a tal 
estado etílico que, cuando se dispone a abrir otra botella con el sacacorchos se da cuenta de que "[...] la punta de l'obridor no s'ha clavat al tap de suro sinó al dors de la seva mà esquerra [...] i que, encara que sembli impossible, no li produeix dolor, ni cap ferida, igual que els faquirs que, després de jeure damunt d'un llit de claus o de caminar descalços sobre una catifa de vidres, somriuen amb una expressió de felicitat idèntica a la que, en aquest moment, il.lumina la cara de l'escriptora." (pág. 69). Obsérvese el paralelismo con la solución que ella había ideado para que su cuento resultara verosímil al lector: "Perquè quedi ben clar que, malgrat que sembli impossible, és versemblant que la protagonista del conte no senti dolor ni sagni, l'escriptora afegeix que la situació de la dona és comparable a la dels faquirs." (pág. 66).

"Nadie", uno de los relatos insertos en la novela de Isabel del Río, La duda — veánse las declaraciones de la autora en nota ${ }^{10}$ - constituye un ejemplo de deliberada implicación autor -lector partícipes de un texto que se va generando en forma de cómo puede contarse ese cuento. El texto se construye a partir de una voz narradora omnisciente, situada en unas coordenadas espacio-temporales indeterminadas y abstractas. El lector interviene en el desarrollo de la trama, en las distintas posibilidades que se van planteando; ve el engranaje del relato por dentro. El final queda abierto, entregado a su imaginación:

"El empleo de la primera persona gramatical permite que el lector pueda no tanto identificarse con el individuo que es objeto del texto como coexistir con él: [...]"

"Esa primera persona evoca, en cierto modo, sentimientos que tal vez también se den en el propio fuero del lector."

"En este ejercicio se entrará en una relación de gradual intimidad con un personaje que aún ha de metamorfosear un él por un yo..." (pág. 237).

"A la confesión en primera persona acompañará información meramente expositiva del entorno o de la acción, [...]"

"Ahora se expresa intimamente el personaje central, pero aún habla de sí como alguien distante de lo que está sucediendo, no menciona en ningún momento el yo [...]" (pág. 239).

Intromisiones de este calibre van alternando en el cuento con el argumento propiamente dicho, narrado en primera o en tercera persona a tenor de las interpolaciones que se van sucediendo.

${ }^{9}$ Construir la novela como una sucesión de relatos se ha convertido en un recurso habitual dentro de la narrativa más reciente. Es el caso de $L a$ duda de Isabel del Río, que reúne una colección de 14 cuentos de carácter metanarrativo, hasta el punto de que J. A. MASOLIVER y F. VALLS recogen éste en su reciente antología (vid. bibliografía adjunta).

111 " ¿Por qué ese interés en diseccionar un cuento, en presentar al lector cómo se escribe? Es la forma que yo he adoptado para atrapar al lector. Quiero hacer del lector un personaje. Quería dar la sensación de que él escribe la historia y yo tan sólo lo llevo de la mano. Así cada lector puede construir su propio cuento." Isabel DEL Río, El Mundo, 29-X-1995. 
En el cuento de Pedro Zarraluki, "La inspiración cáotica", este carácter pseudodidáctico queda manifiesto desde la primera frase: "Para escribir un relato necesitamos un buen escenario" (pág. 13); el yo-emisor pretende enseñar los pasos a seguir para escribir cuentos a un destinatario a quien incluye con el uso de la primera persona del plural "necesitamos"; ambos se encuentran en el espacio de la ficción como si los dos elaboraran juntos un texto según la receta propuesta. Una vez perfilado el marco espacio-temporal hay que dar “entrada [...] a los personajes." (pág. 14) y a los demás ingredientes necesarios. El narrador-preceptor, siguiendo con su propósito, sugiere fórmulas de apertura del relato, alecciona al aprendiz de cuentista sobre los artificios que tiene en su mano, juega con él y le crea falsas expectativas, esboza alternativas argumentales posibles... que va alternando con incisos metatextuales y permanentes comentarios acerca del quehacer literario en curso.

Uno de los recursos más utilizados de cara a indagar en el proceso creativo y recordar al lector la naturaleza de artificio de lo que está leyendo son los desplazamientos de un plano real a otro de ficción y viceversa, sin más restricciones que las establecidas por las reglas de la verosimilitud en el juego literario. Esta mezcla de planos permite al autor cuestionarse las relaciones entre realidad-ficción / vida-literatura, puede dar lugar incluso a reflexiones de corte existencial, aunque la mayoría de las veces sólo persigue la amenidad. Lo original, en estos casos, radica en la destreza con que el escritor sabe atrapar al lector desconcertándole, engañándole o contando con su complicidad.

Complejas estructuras - aunque sin incurrir en excesivo experimentalismo-, acciones paralelas — cuento que leemos / cuento que está escribiendo el autor-fictivo - que pueden llegar a fundirse, límites imprecisos entre realidad y ensueño, presencia de lo fantástico, asentado la mayoría de las veces en la cotidianidad, irrupción de lo insólito, soluciones inesperadas, finales abiertos, sorpresivos o impactantes, materiales intertextuales, juego de identidades y desdoblamientos, diálogos escritor-personaje, comentarios sobre el cuento en curso a cargo del propio escritor-fictivo o de un narrador impersonal; con todo ello suele configurar el autor-real el cuento que nosotros, lectores-reales, leemos. Hasta aquí los planteamientos teóricos veamos, a través de algunos cuentos, cómo los escritores los resuelven en la práctica.

El encuentro fortuito e impactante con un viajero perdido incita al escritor-fictivo a convertirlo en protagonista de un relato. Berta, su compañera, empieza a tener sueños durante varias noches: "Es el hombre de tu cuento" (pág. 15), le dice convencida. A partir de este momento, se producen una serie de coincidencias entre el argumento del texto que está escribiendo el autor-fictivo ( "el viajero perdido", atrapado en un aeropuerto debido a las inclemencias climatológicas, coincide en la sala de espera con una pasajera y se pasan la noche charlando) y una serie de circunstancias personales que está viviendo Berta (retenida también en el aeropuerto por idénticas razones). Son tales las coincidencias, que el autor decide cambiar el argumento "intentando sustituir la relación entre ambos [...] por un suceso de significación totalmente opuesta. [...] Así, la aproximación entre ambos nunca podría ocurrir; [...]" (pág. 
23). Pero éste escapa a sus designios. ¿Ha tenido lugar en verdad el encuentro entre Berta y el viajero, como nos induce a pensar José María Merino en su cuento "El viajero perdido" por medio de una sugerente interposición de planos? El lector tiene la última palabra.

Compaginando la técnica del relato dentro del relato con ingredientes propios de los cuentos de terror y dejando también el desenlace abierto, Ignacio Martínez de Pisón, en su cuento "La muerte mientras tanto", consigue mantener al lector con la incertidumbre hasta el final. A pesar de lo que parecen sugerir las frases inquietantes de esa especie de "diario" que Clara descubre de manera furtiva en el disquet de Pablo, $i$ son, en realidad, simples notas para un proyecto de cuento que quizás algún día escribiré. (pág. 76), según le aclara él para tranquilizarla? ¿Acabará matándola? ¿Cómo interpretar sino este desconcertante párrafo: "Por la mañana Pablo volvió a sentarse ante su ordenador. Buscó el final del texto y corrigió algunas de las líneas ya escritas: 'Dormía como una niña exhausta tras un naufragio. La muerte sólo ha sido para ella un arrecife imprevisto en mitad del sueño"”? (pág. 77).

Lorenzo Fresnos, un detective "con secretas ambiciones literarias" protagonista del relato "Final absurdo" de Laura Freixas, cree haber hallado "un magnífico tema para un cuento" (pág. 53) gracias a la visita de una extraña mujer que se presenta intempestivamente en su despecho pidiéndole explicaciones y recriminándole - “;Es usted uno de esos autores prolificos y peseteros que fabrican las novelas como churros y las olvidan en cuanto las han vendido!" (pág. 58)—, antes de formularle una curiosa petición: "Déme aunque sólo sean treinta páginas más -susurró-, o aunque sean sólo veinte, diez... Por favor, señor Godet..." (pág. 58).

Debe tratarse de una loca - "Se toma por un personaje de ficción" (pág. 58)- que le confunde con un autor de novelas, deduce el detective. Pese aclararle el malentendido, la mujer le propone un trueque, "usted pasa a mi novela, y yo paso a la suya" (pág. 59). ¿Podría tratarse de un sueño, se pregunta Fresno y ella sería, precisamente, la protagonista de la novela que él había estado leyendo antes de quedarse dormido en su despacho? Una explicación plausible, pero he aquí el desenlace ideado por la autora: la exclamación proferida por el protagonista cuando Luisa le dispara - "No puede ser, es un final absurdo..." - y la respuesta que se sigue - "Ni más ni menos que cualquier otro", le contestó bostezando Jesús Godet mientras ponía el punto final." - (pág. 61), nos permiten averiguar que, al igual que la mujer, el detective era también un personaje literario ${ }^{11}$.

El texto que estamos leyendo y el que está escribiendo el autor-fictivo pueden llegar a fusionarse hasta tal punto que el título de ambos relatos sea el

"Un recurso similar se emplea en el cuento "Los temores ocultos" como desvela el golpe de efecto que Luis MATEO DíEz nos reserva para el final: "Volví sobre el escritorio y mis ojos penetraron la desmantelada montaña de folios escritos donde Robert circulaba a través de capítulos llenos de tensión y oscuridades.// Y fue entonces cuando me di cuenta de que vo podia ser el personaje de una historia que alguien estaba escribiendo." (pág. 80). 
mismo: "Llisco la mirada per algunes de les pàgines, [...]. Rellegeixo una vegada més el títol escrit tot amb majúscules: LA POR DEL CAIXER DAVANT LA PISTOLA". Además, el protagonista-escritor - antiguo empleado de un banco había presenciado algunos robos- es consciente de que "no $m$ 'ha de costar trobar la manera de fer-la versemblant, aquesta por, [...]. No m'és exòtica, la situació que hi descric: l'he viscuda en la pròpia pell, del cantó dels bons, tot sigui dit, per més que avui no em costa gens d'imaginar-me a l'altra banda del taulell..." (pág. 8). El autor del cuento —un miembro del colectivo Ofèlia Dracs - funde planos, incorpora ingredientes de la serie negra y también esta vez nos quedamos sin saber a ciencia cierta si el protagonistaescritor acaba cometiendo en su vida real el asesinato que va fraguando en su imaginación.

Sin cambiar de tercio —el protagonista del relato de Ramon Solsona, "La inspiració del novel-lista", se propone también escribir una"novel-la negra"pero sí de tono -dejaremos constancia transcribiendo el final del cuento-, tropezamos con un escritor-fictivo que busca la inspiración en su realidad cotidiana. A falta de cualquier otra idea - "No tenia argument ni personatges, no sabia por on començar"-, empieza a hacer suposiciones sobre la vida de sus vecinos. "Havia trobat allò que buscava. [...] Ara se n'adonava que aquelles persones a les quals saludava rutinàriament des de feia anys constituïen una matèria literària de primera qualitat, eren personatges autèntics de novel.la!" (pág. 108). Cuando pasa revista, piso por piso, todos le acaban pareciendo sospechosos: esconden obras de arte robadas, se dedican al comercio clandestino de vídeos pornográficos, trafican con drogas... Especialmente sospechosa le resulta su vecina del rellano, a quien espía por llevar una vida que él considera muy irregular pero, sobre todo, por su costumbre de andar por casa ligera de ropa. Mientras los dispersaba "en una geografia imaginària" (pág. 111) y escribía páginas y páginas, " la vida a l'escala feia el seu curs." (pág. 112). Y la verdad es que la vida real de los vecinos no tiene nada que envidiar a la imaginada por el escritor en la ficción. El vuelco final que da la trama destaca por lo ocurrente: "La veïna del replà era una jove periodista que escrivia articles a diverses revistes. Havia publicat un llibre d'entrevistes $i$ ara feia les primeres armes en la narrativa, estava molt enfeinada escrivint un relat policíac. Començava així: 'Acabo de matar l'home que m'espiava pel celobert'”. (pág. 114).

Que Clara, una ya famosa escritora, crea oír una "Voz [con] acento extranjero" (pág. 136) que la obliga a escribir sin tregua, o que tenga la certeza de que sus "libros no son más que la transcripción exacta $[. .$.$] de los de [...]"$ (pág. 142), una tal Sonia Kraskowa, instiga al narrador de "En el hemisferio sur" de Cristina Fernández Cubas a convertir esos extraños "desvaríos" en "el punto de partida [...] de la novela que había perseguido durante tanto tiempo." (pág. 150). Pero dicha obra no llegará a ver la luz. Tras la muerte de Clara averiguamos que su verdadero nombre era "Clara Sonia Galván Kraskowa” (pág. 148); la lectura del manuscrito de su obra póstuma nos desvela, además, que todo formaba parte de un "tétrico juego" (pág. 153) previsto por ella: "Hasta aquel momento no habia hecho otra cosa que escribir la vida; ahora, iba a ser 
la vida quien se encargara de contradecir, destruir o confirmar mis sueños..." (pág. 152).

El entramado del cuento "Borrador de una historia" de Antonio Muñoz Molina resulta todavía más complejo en cuanto a fusionar planos se refiere. Escondiendo su personalidad bajo un pseudónimo, su protagonista se dedica a escribir novelas eróticas y policiacas en un mísero cuarto alquilado. Está redactando una historia sobre un detective, "Black Blake", quien, a su vez, lee novelas de "F. Blatsky", precisamente el pseudónimo del escritor-fictivo. Aunque de momento todo está en la cabeza del novelista y la hoja permanece en blan$\mathrm{co}$, se ponen en conocimiento del lector los paralelismos existentes entre el caso que investiga el detective y la vida real del escritor-fictivo.

La ya tópica dialéctica entre autor-personaje nos la presenta Agustín Cerezales en "Diálogo de sordos" comenzando su relato bajo la apariencia formal de una acotación escénica: "Escenario: un despacho [...]. Sentado a una mesa, un escritor, que rellena a pluma, frenéticamente, una serie de cuartillas. En una esquina [...], un joven de tez pálida y expresión abatida, a quién llamaremos el Protagonista.[... ] que empieza a hablar solo.", y sigue un largo monólogo de un cierto corte existencial: "No sé quién soy. No sé dónde estoy. [...] de dónde vengo y a dónde me dirijo". (págs. 165-166); el protagonista se plantea rebelarse contra su autor por actuar con él como un demiurgo y "poder volver atrás sobre una hoja escrita y tachar, añadir, perfilar, sesgar, trucar [...]", pero decide al fin "que será mejor cerrar los ojos, [...] aguardar a que él decida sacarme al exterior, y ver qué se le ocurre hacer conmigo." (pág. 167). La respuesta del autor a este soliloquio no se hace esperar, tras otra acotación, intenta eximirse de su responsabilidad: "Los escritores que lo somos de verdad carecemos de criterios propios, somos simples y puros transmitentes, puentes entre el mundo de los muertos y el mundo de los vivos. [...], si [...] desertásemos a la primera dificultad y se interrumpiera este sagrado y sempiterno tránsito [...] ¿qué sería del mundo, existiría el mundo, en realidad?" y "Cae el telón" (pág. 169).

Sentado ante su máquina, el protagonista-escritor del cuento de Gonzalo Suárez "Interludio" nos va adentrando en el relato que está escribiendo: un coche circula por una carretera en una noche de lluvia, rumor de las olas... Argumento y ejecución discurren paralelamente; le falta dar vida a los personajes. Éstos se le imponen: "El escritor todavía no conoce la identidad de los personajes. Surgieron, de pronto, en el interior del coche, mientras él encendía un cigarro, sobre el teclado de la máquina de escribir." (pág. 126).

Hacer literatura de la literatura - reflexiones metaliterarias - contempla también el recurso de insertar en la trama de un relato toda suerte de materiales intertextuales (referencias a autores reales, a personajes de ficción de otros autores y obras literarias sobradamente conocidos, menciones a otras obras de los propios escritores...) que no están traídos a vuelapluma, sino que van jalonando el cuento y encuentran su sentido en el transcurso de la narración. Traemos a colación algunos ejemplos. 
Màrius Serra, por ejemplo, hace que el protagonista de "Transcripció", que a su vez es escritor, compre "Amigos que no he vuelto a ver" de "Ignacio Vidal-Folch", lo vaya leyendo, "El vaig començar $[. .$.$] i em vaig enganxar tant$ que me'n vaig llegir més de cent pàgines" (pág. 20 ), y nos explique de qué van las seis narraciones leídas hasta el momento; o que le preste "Olivetti, Moulinex, Chaffoteaux et Maury" (pág. 24), una colección de cuentos de Quim Monzó, a una amiga, libro que él mismo acababa de leer. Serra llega hasta el extremo de convertir a este famoso autor catalán en protagonista del sueño que está transcribiendo el autor-fictivo de la narración que leemos.

En "Postil.la", incluido en el mismo volumen que el cuento anterior, $L a$ vida normal, el protagonista-narrador atribuye a un supuesto amigo la autoría de la novela, Mon oncle, obra del propio Màrius Serra. A través de "aquesta crònica" (pág. 148), lo que simula estar escribiendo, sabemos que el argumento de la citada novela tiene mucho de autobiográfico, explica asimismo ciertas contrariedades que tuvo que sortear su amigo el escritor para poder publicarla. En literatura vale todo, pero no se trata, esta vez, de un mero subterfugio dada la afinidad de circunstancias entre lo que cuenta el relato y lo sucedido en realidad con dicha novela, según refirió Màrius Serra con motivo de su publicación ${ }^{12}$.

Hércules Poirot, el célebre detective protagonista de gran parte de novelas de la Ágatha Christie, será quien acabe asesinando a la famosa escritora en el cuento de Manuel Vázquez Montalbán "El alevoso asesinato de Ágatha Christie", porque "-La vieja bruja me había hecho muchas pasadas, muchas, a lo largo de los años. Fijense qué cabeza me había atribuido y qué estatura. Mon Dieu! No hay detective privado en el mundo más grotesco que yo. Holmes tendría sus defectos y rara intimidad pero era más esbelto. ¿Y los americanos? Marlowe, Spade, apuestos, hermosos. En cambio yo...-" (pág. 108).

Es, precisamente, "un llibre d'aquella anglesa que li diuen l'Àgatha Christie, L'assassinat del Roger Ackroyd" (pág. 70), el motivo desencadenante de la agresión que comete Damià, protagonista del cuento de Jesús Moncada que lleva el mismo título que la novela inglesa. Voraz lector de historias de detectives, confiesa al juez -declaración que va intercalando en las páginas del cuento con el argumento de la famosa novela - haber pegado un tiro de escopeta a un vecino del pueblo porque, totalmente inmerso en la lectura - "cada vegada m'engrescava més amb les invetigacions de l'Hèrcules Poirot" (pág. 74)—, intrigado por descubrir al asesino, Teodor de Peris con un "gest mofeta i cruel" (pág. 75), le revela su identidad.

Sherlock Holmes y su inseparable Watson se prestan también a este juego intertextual en el relato de Carlos Pujol "La ficción", al producirse una inversión de papeles entre el autor y los personajes. Leamos unos fragmentos del diálogo: "Las historias las firmará ese fantasma [Arthur Conan Doyle, que figura han

${ }^{12}$ Otro ejemplo de autorreferencialidad nos lo ofrece Jordi Llavina en su cuento "La mà esquerra de don Roger", al hacer entrar en la trama su reciente antología La mà tallada, pág. 233-239. 
inventado ellos] para cubrir las apariencias, [...] pero el narrador seguiré siendo yo, Watson, y en cuanto a usted, que es el protagonista, nada cambia". Holmes le replica: "-Se equivoca. Cambia el hecho de que usted y yo somos de verdad, y el que va a figurar como autor de esos relatos no. El personaje de ficción es él, parecerá que somos nosotros, lo cual es algo contra natural-". (s/p).

Hechos tales como que don Amadeo se hubiese "echado para atrás en el momento mismo de la boda, [al haber] pillado a la novia una mirada, [...] y [...] [comprender] [...] que ella se casaba por conveniencia", como sucedía en "El encaje roto de doña Emilia Pardo Bazán"; o que, acompañando a don Amadeo en ambulancia al hospital a que "le sacaran el hueso de pollo que se le había atravesado en la tragadera", le viniera a la cabeza"el conocidísimo cuento de Maupassant, que es el mismo accidente penoso y cuadraba como anillo al dedo." (pág. 155), le parecen fácilmente justificables al protagonistanarrador del relato de Antonio Pereira "Coleccionistas de historias": "Esta ciudad nuestra la fundaron los peregrinos, que contaban sucedidos, y nos ha quedado este gusto, no es raro que para las cosas diarias nos refiramos a cuentos famosos" (pág. 154).

En "Una història lamentable" Ramon Solsona —además del recurso autorreferencial de inventarse él mismo como personaje — va un poco más allá, esta vez el personaje se rebelará contra su editor, un editor con nombre y apellido verdaderos: Jaume Vallcorba. La trama, con características relato policial, asesino a sueldo contratado para matar-, se ve interrumpida en sucesivas ocasiones por advertencias tales como "Senyores $i$ senyors, per problemes tècnics, el relat ha quedat interrumput momentàniament. Esperem reprendre'l ben aviat. Moltes gràcies." (pág. 142), a la espera de subsanar "els problemes tècnics [...] , els preguem que no canviïn de llibre." (pág. 144), "els deixem en companyia de Madonna: "(pág. 149) —letra de la canción incluida—; entre estas justificaciones se va intercalando la discusión que tiene lugar entre el citado editor y el personaje - el asesino a sueldo-, quien le comunica su decisión de cambiar de autor y de género: "Vull sortir en una novel-la rural". Puestos a escoger, preferiría ser un personaje de Jesús Moncada antes que de Maria Barbal o Pep Coll, y si acabó siendo personaje de Solsona, alega el protagonista, es porque "- - ...] Comprenc que no tinc prou tremp per a en Monzó $i$ de'n Pàmies no te'n pots fiar, només et fa servir si se li posa malalt un personatge. $M$ 'ha tocat en Solsona, què hi farem, un conte passa aviat. Així que acabi aniré a veure en Moncada, [...]-" (pág. 143).

En medio de los descabellados diálogos entre el asesino y su futura víctima y las interpolaciones, tenemos noticia de que Jaume Vallcorba y Ramon Solsona han aparecido muertos en extrañas circunstancias, lo que obliga a interrumpir definitivamente el relato, previa inserción de la última advertencia: "No ens fem responsables de la continuïtat d'aquesta lamentable història sense cap ni peus que ja haviem d'haver tallat fa unes quantes pàgines." (pág. 154). Solsona aún se reserva el último párrafo para que el protagonista, que no ha desistido en su empeño, se presente en casa de Jesús Moncada y le vaticine: "Vostè i jo farem grans coses." (pág. 155). 


\section{I.2. FueNTES DE INSPIRACIÓN}

Lo mismo que todo lo referido al proceso de creación de la obra, indagar dónde encuentran los escritores argumentos para sus historias es cuestión que despierta el interés de críticos y hasta de lectores. Los escritores-fictivos se convierten en alter-ego del escritor real, a tenor de las respuestas dadas cuando se les pregunta sobre sus fuentes de inspiración: los hay a quienes les basta con el día a día, como el protagonista de "Documentació" de Màrius Serra:

"Res de viatges visites consultes entrevistes transformades en inversions desgravables al servei de la narració amb què l'escriptor professional ocupa la seva jornada. Res d'actes de servei per a la causa d'una ficció que simula la realitat tant com pot. No estic disposat a ser un d'aquells escriptors que viuen a la recerca d'una informació susceptible d'alimentar la màquina d'escriure que aspiren a esdevenir. La vida normal és l'única vida possible i la literatura sempre en prové, tot i que al final acabi en una altra banda." (pág. 125).

El escritor del cuento de Muñoz Molina "Borrador de una historia", en cambio, lo mira todo en los quioscos y casi todo lo compra, especialmente revistas obscenas, semanarios de crímenes, porque "[...] un escritor debe conocerlo todo, y los mejores argumentos no son los que se inventa uno, sino los que vienen en la sección de sucesos, las cartas de los consultorios sentimentales, esas historias de la vida real donde una joven cuenta con pormenores culpables cómo un embarazo y un galán desalmado la arrojaron al arroyo." (pág. 193).

Pero también puede avivar la imaginación del autor un sueño - "sé, o crec saber, què m'ha empès a transcriure un somni per primera vegada a la vida i perquè després del primer paràgraf que vaig escriure diumenge al matí he seguit, fins ara, un parell de dies escrivint $i$ reescrivint aquesta narració [...J" (pág. 20) "Transcripció"-, algo que le han contado - "M'ho va explicar de passada una amiga en un sopar i ja no m'ho he pogut treure del capág." (pág. 29) “[...] Vaig agafar un bolígraf $i$ vaig decidir transcriure la història tal com me l'havien contada." (pág. 32) "Incert so" —o una imagen persistente— "[...] el recuerdo del viajero perdido no se esfumó de su imaginación [...]", (pág. 10), "Persistía en su mente aquel rostro despavorido sobre una figura empapada, adquiriendo la brumosa consistencia de los elementos novelescos. Se levantó para recoger el cuaderno de apuntes y un bolígrafo y redactó unas notas. "El viajero perdido".

Detengámonos un poco más en lo que supuso como acicate para Toño Llamas el "descubrimiento del cadáver incorrupto de su bisabuela" (págs. 5859). Tras investigar el caso a fondo escribe La bisabuela incorrupta, obra que en quince años aún no llega a publicar, a la espera de que murieran las personas que aparecen, puesto que - se nos aclara - no se tomó ni la molestia "de cambiarles los nombres a los protagonistas de la historia en su trasposición a la novela." (pág. 66). Harto de esperar a que muera "Lupicinio el Mudo", el 
último que quedaba, Toño decide atropellarle, acción que el narrador exculpa con un paréntesis - "(la verdad es que Toño Llamas jamás hubiera llegado a esos extremos de no haber sido por la literatura)", (pág. 70)—. Tras fracasar en el intento,Toño huye y se esconde en algún lugar de Asturias, donde da clases de conducir, precisamente, mientras "escribe otra novela, ésta ya experimental del todo, $[\ldots]-y$, por supuesto, sin un solo personaje-, sobre la incorruptibilidad de la literatura" (pág. 71). El título escogido por Julio Llamazares para el cuento que leemos, "La novela incorrupta" está en consonancia con las sarcásticas apostillas que va desperdigando por el texto su narrador omnisciente.

\section{I.3. HeRramientas}

¿La informática ha modificado los hábitos de escritura y sus resultados? ¿En qué momento y cómo hacen uso del ordenador? se les pregunta con frecuencia hoy en día a los escritores. El abanico de respuestas es amplio y para todos los gustos ${ }^{13}$. Autores consagrados y aprendices del oficio pueden encontrar en el mercado títulos tales como Guía para el uso del ordenador en la creación literaria. Huelgan comentarios.

El lápiz, la pluma, el cuaderno, la hoja en blanco... no es que hayan quedado definitivamente atrás, pero sí un tanto postergados frente a esta nueva herramienta de trabajo para el escritor que, todo hay que decirlo, cuenta también con sus detractores. Tema tan candente era de esperar que acabara ficcionalizándose de los más variados modos y maneras: ventajas, inconvenientes, peligros - reales o imaginarios- que comporta su uso en el proceso de escritura..., son traídos a colación en los cuentos seleccionados. No resultan infrecuentes los toques de humor ni falta el componente fantástico como veremos.

Jordi Planesdamunt, el protagonista de "La matèria dels somnis", un "escriptor professional en llengua catalana" (pág. 9), resulta seleccionado por

1. - "El ordenador cambia el estilo, no me cabe ninguna duda. Lo agiliza pero lo despoja de cierto poso sin el cual mi literatura perdería todo aliciente. Cuando he intentado escribir en ordenador, me sale una prosa de notario de provincias o cura párroco." Juan Manuel DE PRADA, Qué leer, n. ${ }^{\circ} 24$, verano 1998, págs. 120-121.

- “'...] Suposo que el mitjà condiciona el resultat. D'ençà que empro l'ordinador [...] també ha canviat el meu ritme de creació i els meus hàbits; ara puc escriure tant o més ràpidament que a màquina i tinc encara moltes més possibilitats de canviar sobre la marxa que quan ho feia a mà." Pep ALBANELL, "Escriure a ordinador", El País, 25-IX-1986.

- "Mucho. Los que escriben directamente en ordenador colocan multitud de subordinadas que musicalmente no funcionan. La herramienta deja siempre una huella material en la obra.", Félix DE AZÚA, Qué leer, n. ${ }^{\circ} 22$, mayo 1998, pág. 112.

- "Escribo siempre a mano y con pluma", "y luego, cuando el texto está ya muy tocado, lo paso al ordenador", Pedro SORELA.

- "Suelo utilizar [para escribir] el ordenador portátil, pero también me apaño con un lápiz y un trozo de papel", Soledad Pú́rTolas.

Marta Rivera. "De la pluma al ordenador", Leer, año 98, n. ${ }^{\circ}$ 5-6, págs. 121-122 
una empresa japonesa para" [...] inventar, ordenar i estructurar una història de ficció, i [...] redactar-la [...] amb l'ajut del DB 2001, un ordinador de nova planta per a ús d'escriptors." (pág. 11) "[...] El nostre aparell [...] significa una revolució en el món de la literatura, de la lingüística i del ram editorial" (pág. 13), le aclaran el asesor y los técnicos de la empresa, japoneses todos ellos, quedémonos por ahora con este dato.

No se trata, en realidad, de un ordenador convencional, sino de un sofisticado artefacto al que hacen funcionar los impulsos mentales del escritor, quien se limita a colocar sus manos sobre una especie de superficie iluminada que lleva adosadas tres grandes pantallas. "Un acte gratuït $i$ inútil -codificar amb paraules idees, sensacions, sentiments-s'havia racionalitzat i esdevenia un acte lògic, racional, analitzable. [...] Jo havia pensat una idea, unes sensacions, havia triat unes quantes paraules-clau i la màquina, en qüestió de segons, havia suplantat el meu esforç, la meva personalitat, la meva capacitat de seleccionar paraules, ritmes, expressions. M'havia xuclat l'essència i l'havia utilitzat en favor seu." (págs. 19-20). Asustado por el poder de la máquina, el escritor decide rescindir el contrato. De vuelta a casa, cuando todo parece haber vuelto a la normalidad, comprobamos que no ha salido incólume de la experiencia: al mirarse en el espejo descubre en su cara rasgos orientales, nada menos.

"El que llegiré no és un conte ni té res a veure amb la ficció, encara que, a estones pugui semblar-ho. [...] És [...] La denúncia d'una situació que ja afecta alguns escriptors aqui presents però que aviat repercutirà en la majoria de contistes de l'Estat, tant els que escrivim en les llengües minoritàries com els que ho fan en castellà". Con este tono apocalíptico introduce Carme Riera su cuento de título paradójico, "Això no és un conte", simulando que se trata de una ponencia leída por la autora barcelonesa Andrea Hurtado, poco antes de morir, en un encuentro de escritores; dichas páginas "me les regalà, pregantme que jo m'ocupés de la seva publicació", nos aclara el narrador para justificar que vean la luz.

Mientras refiere cómo redacta unos relatos veraniegos de encargo, uno de ellos " $[\ldots]$ sobre la creació literària i les limitacions materials que, de vegades, l'envolten: ' $[. .$.$] ordinadors que es declaren en vaga, [...]'" explicita,$ Andrea Hurtado aprovecha para declararse una experta en informática y no duda en reconocer las ventajas del ordenador a la hora de facilitar el proceso mecánico de la escritura: " [...] vaig comptabilitzar el nombre de repeticions de la paraula inclús, vaig prémer el comandament de substitució, aparegueren fins i tot, a més, també, vaig veure amb gust com les lletres s'arraïmaven [...], per deixar lloc a les nouvingudes, [...]" (págs. 164-165). Es justamente su sofisticado último modelo conectado con la central informática de IBM lo que le permite hacer el descubrimiento preocupante del que quiere dar cumplida cuenta en la citada ponencia. Cuando se dispone a hacer una última revisión de uno de los cuentos descubre que "[...] en pantalla [...] apareixien tot de referències en clau que, després de molts esforços, vaig aconseguir desxifrar $i$ que remetien a obres de Pere Calders, Torrente Ballester i Borges, entre altres, com José M. ${ }^{a}$ Merino o Marina Mayoral, [...]". 
Finalment, després del poti-poti de referències, l'ordinador m'oferí un text nou, una suma de textos diversos, un text realment magnífic però que en absolut no podia reconèixer com a meu. (pág. 167). [...].

Fou aleshores quan, [...] vaig arribar a descobrir que el meu conte havia servit de conill d'Indies per als experiments d'un grup de critics i professors, [...], per dissenyar [...] una gran màquina contadora, programada amb tots els contes possibles, procedents dels autors més diversos, en totes les llengües del món. Bastarà que qui l'adquireixi la sàpiga manejar perquè ella organitzi un conte nou $i$ distint, un conte original, gràcies al savi maneig de la intertextualitat i de l'intratext, el millor conte possible entre tots els contes explicats o per explicar. [...] Si l'invent prospera, no sols arrü̈narà aviat les nostres carreres de contistes, sinó que, a més, ens convencerà de seguida que mai no serem dignes de competir amb la màquina contadora i que, per molts esforços i dedicació que posem a escriure contes, ella sempre ens guanyarà." (pág. 168). Éste es el grave problema que planteó la escritora en su día para debate, ¿qué hacer con la máquina contadora? Ella lo tiene claro: "A les barricades! Mori contadora!" (pág. 169).

Es el incentivo económico - otro motivo recurrente según hemos constatado en muchos de los relatos escogidos- lo que mueve al protagonista de "Es gasten els llapis quan se'n va la llum?" a aceptar la propuesta de escribir una novela negra, a pesar de declararse reacio al género, en un mes, para una colección de quiosco muy bien pagada. Le llega en un momento en que decide introducir cambios notorios en su vida y, puestos a cambiar, también lo hace con sus hábitos de escritura: "[...] vaig decidir [...] comprar-me un ordinador. Sempre havia estat contrari a aquestes màquines, fins $i$ tot havia defensat l'escriptura a mà en més d'una entrevista, però l'ànsia de canvis em va impulsar a comprar-lo." (pág. 151). Combinando los ingredientes típicos del género - "embolics, droga, diners, dones fatals, homes durs i trets a dojo"-, se pone a escribir a destajo para poder cumplir con el plazo fijado. Pero... gajes de la técnica! "[...] quan ja enllestia l'última revisió, va passar un fet inesperat $i$ dramàtic: se'n va anar la llum. La pantalla de l'ordinador es va apagar de cop, va quedar només un punt il.luminat al centre, $i$ just en aquell moment vaig recordar, massa tard,l'advertència del venedor sobre la conveniència de protegir de tant en tant el text per evitar que se m'esborrés per accident." (pág. 159). Había perdido toda la novela.

Cualquier subterfugio es válido para urdir una ocurrente trama: la pérdida accidental de lo escrito ${ }^{14}$, la máquina que supera al escritor, la aparición en pantalla de textos de misteriosa procedencia...

${ }^{14}$ Casimiro Rebollo no es que sea un entusiasta de la máquina; llega a culparla incluso de su propia impericia como narrador: "batallaba ardorosamente con su pequeño ordenador personal, a cuya demoníaca facilidad para sacar y poner textos, para transformar y redondear capítulos, culpó de descentrarle en numerosas ocasiones. Justo en esos momentos críticos en los que la inspiración irrumpe [...], evanescente e irreal, presta a verter en la conciencia una [...] ducha de genio." (págs. 25-26). Al final, le jugará también una mala pasada: "I...] por un desgraciado accidente se borró ese diskette en el ordenador antes de que llegase a imprimir en folios el capítulo cuarto. Por una vez en su vida había cedido ante el empuje de la inspiración. Era casi todo improvisado. l... . Por una vez en su vida no tomó precauciones contra esas pérfidas máquinas." (pág. 48), "Crítica de la Razón Impura". 
Esto último es lo que convierte en inquietante al relato "La pantalla" de Jaume Subirana. En tres ocasiones sucesivas, mientras el protagonista está redactando los artículos para la revista de una compañía aérea - bien remunerados, se nos precisa de nuevo-, le aparecen tres extrañas historias de similares características - transcritas en el relato que leemos - y que el personaje no tiene constancia de haber escrito. Averiguar la procedencia de dichos textos llega a ser una obsesión, puesto que nadie usaba su ordenador y él no trabajaba nunca con disquets que no fueran suyos: "S'adonava que $[. .$.$] no podien$ haver entrat a l'ordinador per ells mateixos $i$, doncs, que havia d'haver estat ell qui els escrivís. Com que no se'n recordava i tampoc no va trobar-ne cap prova ni cap esborrany entre els seus papers, va decidir que devia haver-ho escrit d'una manera inconscient, mentre dormia, per exemple, o posseït per una segona personalitat de què fins aleshores no tenia notícia." (pág. 177). Obsesión que va a más, hasta tal punto que lo encuentran al cabo de unos días "assegut com un pobre idiota davant de la pantalla de l'ordinador" (págs. 184) en la que se podía leer un breve texto inacabado: "Deixa de mirar". Estamos ante un caso de doble personalidad, según parece sugerir el final del cuento: "Ara ja no sóc qui era, és clar, sóc un individu nou. Ell, l'altre, va quedarse allà, aterrit, incapaç d'apagar l'ordinador. Jo vaig saber imposar-me, vaig decidir i vaig actuar." (pág. 186).

Pero no sólo el ordenador gasta malas pasadas al escritor. Justamente cuando el protagonista del cuento de Quim Monzó "Thomson, Braun, Corberó, Philishave...", tras una suerte de peripecias, consigue que le reparen la calefacción y los electrodomésticos averiados y decide sacar partido de los percances sufridos conviertiéndolos en materia literaria, es su vieja Olivetti la que le impide escribir su relato. "Havia d'escriure-ho tot: des de la sortida de la ciutat fins a l'arribada del barbamec; encara més: fins aquest precís moment que, reintegrat tot en la normalitat, s'asseia davant de la màquina i trobava el desllorigador. [...] De cop, però, una tecla de l'olivetti saltà enlaire, en un bot acrobàtic. En segons, la màquina es desencaixà: quedà reduïda a una pila de cargols, barretes i molles." (pág. 31).

Todavía hay escritores apegados a sus viejos hábitos escriturales, siguen prefiriendo el papel y la pluma que, tanto en la realidad ${ }^{15}$ como en la ficción, se ha convertido en objeto de culto para el escritor.

"Cada escriptor té els seus costums, quasi es pot dir les seves petites manies i obsessions. A mi, per exemple, m'agrada de començar qualsevol llibre escrivint amb estilogràfica. Després, [...] quan estic ben embrancat, em poso a la màquina elèctrica, i endavant. No, no tinc ordinador" (pág. 55), confiesa Adrià, el protagonista del cuento "L'estilogràfica" de M. ${ }^{a}$ Angels Anglada. En plena crisis creativa, su mujer le regala una vieja pluma: "M'han assegurat que és la ploma, [...] del poeta Émile Verhaeren." (pág. 57); escribiendo

${ }^{15}$ Reconocía Félix DE AzÚA en una entrevista su inveterada costumbre de estrenar una estilográfica nueva cada vez que empieza un libro. Qué leer, $n .^{\circ} 22$, mayo 1998. 
con ella le vuelve la "inspiración": "L'estilogràfica s'havia encomanat l'energia del poeta belga, [...] quan vaig tornar a començar la novel.la, amb la nova ploma, [...] les paraules venien, amanyegades, dòcils. (pág. 57). Consigue acabar la novela con la que gana, además, un importante premio, y la convierte en otro de sus fetiches: "Encara atribueixo una bona part del seu encert a l'impuls que em donà l'estilogràfica de Verhaeren. No l'he feta servir per a cap altra obra; la guardo, amb unes quantes d'altres, a la vitrina on tinc la modesta col-lecció d'objectes relacionats amb l'escriptura i els llibres: tinters antics, alguns tallapapers de plata, plomes manuals, tampons per a ex-libris...En tinc prou de mirar-me'l per posar-me content, el meu petit talismà, disfressa inesperada d'una musa amable. (pág. 58). Nunca llegará a saber que se trataba de una falsificación.

\section{MUNDILLO LITERARIO}

"La vida literaria es un pasatiempo más o menos recreativo que a muchos les consuela de la literatura, del mismo modo que [...] la literatura dicen que consuela de la vida. Así, [...]: en lugar de vivir se escribe, y en lugar de escribir uno se agita nerviosamente en torno a cuestiones públicas y ruidosas que tienen que ver con los libros, y que acaban siendo más importantes que los libros.

Proyectos, tertulias, chismes de la profesión, premios cuyos ganadores se conocen dias antes, críticas elogiosas u hostiles, conferencias, simposios, contratos, agentes y anticipos, políticas editoriales, cifras de ventas, traducciones extranjeras, éxitos [...] y fracasos [...].

Todo eso, tan volátil, entre el humo de colores y el chasco, es la comedia y el estruendo que rodea una actividad, la de escribir, por esencia solitaria y silenciosa [...]" Basta este somero esbozo para demostrar, a todas luces, que el escritor Carlos Pujol conoce bien el actual panorama literario ${ }^{16}$.

La proyección social del escritor y su obra, el papel del libro convertido en puro objeto de consumo, sujeto a las implacables leyes del mercado, lo arbitrario de los éxitos y fracasos editoriales, el servilismo con respecto a los índices de ventas que ha llevado a confundir la cantidad de libros publicados/vendidos con la calidad (triunfo de la literatura-basura), la sumisión a las modas, la función de los críticos, la incidencia de los mass-media y las nuevas tecnologías, la proliferación de premios, talleres y métodos de escritura creativa. Un mundillo literario, en fin, en el que impera la farsa, los espejismos de la fama, en el que se dedican más esfuerzos a la promoción que a la creación, de éxitos efímeros y figuras de relumbrón. De ahí que ironía, sarcasmo, humor, parodia

${ }^{16}$ Carlos Pujol, "Vida literaria", Tarea de escribir, Pamplona, Pamiela, 1998, pág. 47. 
o sátira, en elevadas dosis, sean los recursos imperantes en los numerosos relatos en los que, aunque sea tangencialmente, alguna parcela de esta realidad deja su impronta ${ }^{17}$.

La muerte del insigne novelista, "R.J", una "gloria nacional" (pág. 11), se convierte en un acontecimiento social de primer orden: "[...] los periódicos dieron la noticia. [...] En la primera página, bajo los llamativos titulares, habia una foto a tres columnas, en las que se veía al anciano moribundo, en su lecho de muerte, y junto a él a nuestro joven ministro de Cultura imponiéndole todavía una condecoración sobre el pijama." (págs. 15-16); acuden ministros, editores de todo el mundo, representantes de instituciones nacionales y extranjeras relacionadas con la cultura. Es el momento que el octogenario protagonista del relato de Juan José Millás, "El pequeño cadáver de R.J.", aprovecha para hacer público un fraude por expreso deseo del difunto.

El primer encuentro entre ambos se produjo el día en que R.J. entregó al narrador - joven promesa de las letras por aquel entonces- un texto que dijo haber escrito, para que le diera su opinión. Aun cuando advirtió que aquel cuento no era de R.J sino un relato suyo publicado años atrás (pág. 17), el narrador decide seguir "su juego": "Es más, [a raíz de aquel suceso] se me ocurrió una historia para un cuento que no llegué a escribir, y que recorrería mi vida para acabar por convertirse en este informe." (pág. 18). Durante los años siguientes, aunque la notoriedad de R.J va en aumento y se decía que estaba trabajando en una novela"cuyo éxito sería definitivo para la consolidación de su prestigio", no había vuelto a escribir. "Era, pues, uno de esos sujetos que viven en los aledaños de la literatura y que, por una rara habilidad, acaban por ser aceptados como novelistas, aun sin haber publicado ningún libro." (pág. 19). Un nuevo encuentro entre ambos en un congreso de escritores y el intercambio de sus respectivas ponencias propuesto por R.J. supone su espaldarazo definitivo, que coincide con el progresivo declinar de la carrera literaria de nuestro narrador. Tras ver rechazada su última novela por varias editoriales, decide mandársela a R.J. y, al poco tiempo, "[...] comenzaron a aparecer en la prensa noticias relacionadas con la próxima publicación de la esperada novela de R.J. Las primeras ediciones se agotaron antes de ponerse a la venta, y numerosas editoriales extranjeras pagaron grandes sumas por los derechos de traducción." (pág. 23). Desde entonces, cada vez que terminaba una novela, se la mandaba a R.J. a cambio de un talón sustancioso. Este era el secreto que compartieron durante muchos años y que R.J., en su lecho de muerte, le pidió que desvelase.

Para conseguir el triunfo en ese mundillo, o lo que parece ser prioritario hoy en día, para llegar a ser un "hombre público", _- "el [lugar] más codiciado por los escritores [que] significa estabilidad, dinero, fama y, con un poco de suerte,

\footnotetext{
17 "Modernos","exquisitos", "marginales", "ladrilláceos","liricos","reporteros", "exóticos", "clásicos", "experimentales", "advenedizos","provocadores", "académicos", "divertidos", "malditos"y "listos" (pág. 30), con tales etiquetas de su invención Casimiro PorRas Rebollo, el protagonista de "Crítica de la Razón Impura", confecciona una lista en la que quedan contemplados todos los especímenes que pululan en el actual panorama literario español.
} 
desde él se da el salto a la gloria" (pág. 20), "El pequeño cadáver de R.J."-, el autor debe prodigarse en encuentros de escritores y congresos, las páginas de periódicos y revistas de gran tirada, programas radiofónicos y tertulias televisivas, jornadas, simposios, mesas redondas, etc.; llevar una intensa vida social, en definitiva. De ahí que el agente literario del protagonista-escritor del cuento de Xavier Moret ya citado, exclame con alarma cuando éste decide aislarse en un perdido pueblo para escribir: "-Sol i sense telèfon! [...] És com un suïcidi!! I els còctels literaris? I els contactes? Què pretens? T'oblidaran de seguida si no freqüentes els ambients. Que no et coneixes la història?_" (pág. 152).

" $Y$ es que un cuento magistral, [...] un cuento esmerado sale con mucho decoro en la Revista de Occidente o en el papel verjurado de El Extramundi, pero donde uno arregla el mes es publicando en los poderosos." (pág. 220), reconoce el cínico protagonista de "Una semana y un día", un escritor de medio pelo mantenido por su amante: "A Silvia le gusta mirarme cuando hablamos de mis cuentos después del amor; creo que últimamente le dedicamos más tiempo a la conversación que a pecar, [...]" (pág. 220).

Mientras está pensando posibles argumentos para futuros relatos, recibe la llamada de Miguel Arosa, el director de una importante publicación, para pedirle "una cosilla para el dominical del periódico" (pág. 222), aunque no se llama a engaño, "Estaba claro que alguien les habría fallado en el último momento. Pero las cosas son como son, y sería salir con el Montalbán, el Marías, [...] puede que con Camilo." (pág. 223). Despacha el cuento en un fin de semana, rematándolo con un final feliz, "es lo que te piden en un relato de verano." (pág. 224), apostilla el personaje. No obstante, una vez escrito, decide publicarlo en el "Rey Lagarto", una anodina revista local, arguyendo: "Y por qué no darme el gustazo de dejar plantado a Arosa, la de veces que el cabronazo silenció mis libros en el suplemento que todos sabemos." (pág. 224).

Escribir por encargo se ha convertido también en una práctica habitual de escritores dispuestos a profesionalizarse a toda costa, aunque sea en detrimento de la calidad que no tienen nada que ver con el índice de ventas. Sírvanos otro cuento de Quim Monzó, "La literatura", a título de ejemplo:

"L'escriptor té un contracte amb una editorial per escriure una novel.la l'any. Fa disset anys que el va firmar $i$, metòdicament, cada mes de gener lliura la nova novel.la a l'editor. Ha publicat, doncs, setze novel.les. Escriure una novel.la no li sembla res d'especialment dificil $i$ es burla per sistema dels escriptors que triguen deu anys a fer-ne una. De vegades en queda més satisfet; de vegades menys. De vegades la història li surt fluida, s'hi apassiona, l'escriu gairebé a raig $i$ la corregeix amb plaer. Altres vegades la història és forçada, [...] (perquè, per contracte, ha d'acabar-la sigui com sigui abans que passi l'any) i la corregeix poc i sense ganes. Tant és: ningú no es queixa quan li surt fluixa. L'exigència de qualitat en aquest seu país és mínima, una cosa tan sabuda que els mateixos habitants se'n burlen. La constància, doncs, li permet viure, precàriament però sense haver-se de llevar a les 
vuit del matí. L'únic que prega a aquest Déu en qui no creu és no tenir mai un bloqueig davant del full en blanc. [...]" (págs. 95-96).

El protagonista de "Borrador de una historia", por su parte, nos ofrece una buena muestra de lo rentable que puede llegar a resultar la literatura-basura: "[...] compra los periódicos serios y mira las páginas culturales con un poco de rencor, porque vienen fotografías de escritores. Los entrevistan, ganan premios, acuden a congresos. Él no está muy seguro de que sea escritor, nunca lo han entrevistado ni ha recibido invitación para asistir a ningún congreso, [...] porque no lo conocen, su foto no ha aparecido en la sección de libros de ningún periódico, ni siquiera su nombre, pero cómo iba a aparecer, si escribe con pseudónimo, Frank Blatsky. A ver quien ha escrito y vendido más libros que él, cuál de esas luminarias que reciben premios está en los quioscos de todas las estaciones, en las calles de cualquier ciudad: Espectros y torturas, [...] Las calientes vampiras de las SS, [...], y también novelas policiacas, las que él prefiere escribir, aunque en la editorial le exigen que tengan algo más de sexo que de crímenes." (págs. 193-194).

¿El escritor nace o se hace? ¿se puede aprender el oficio? ${ }^{18}$, son algunas de las eternas cuestiones objeto de controvertidas polémicas. Por cómo proliferan actualmente los Talleres de Escritura o Escuelas de Letras, los fascículos o publicaciones con recetas para aprendices de escritor -Manual para cuentistas, El arte y el oficio de contar historias, Guía del escritor- podríamos pensar que hoy en día se cree que cualquiera puede llegar a serlo. La narrativa breve no podía dejar de hacerse eco de este fenómeno.

Lucas Lerma decide sacrificar sus vacaciones veraniegas y matricularse en una escuela de letras. El narrador del cuento titulado "El alumno", de Felipe Benítez Reyes no escatima comentarios sarcásticos a tenor de la decisión adoptada por el personaje - " (qué era una playa, a fin de cuentas, al lado de la revelación de todos los secretos literarios habidos y por haber; muy poca cosa, efectivamente)"-, y da rienda suelta a la ironía y la sátira al referirnos puntualmente la suerte de actividades que en ella se practican: La primera semana habia resultado especialmente emotiva: los profesores se fueron presentando unos a otros como "el mejor novelista de la promoción madrileña del 80", "el más destacado representante de la poesía de los 70", "uno de los autores más traducidos de nuestra narrativa", "tal vez el crítico más lúcido de...". La segunda semana "la literatura le acabó mostrando a nuestro personaje los colmillos: teorías que resultaban más alambicadas de la cuenta para su entendimiento, nombres de críticos y escritores extranjeros que pasaban a sus apuntes con una dudosa transcripción fonética,[...]" (pág. 109) "[...] títulos, exégesis, [...], poesía visual y concreta, Oulipo, hermenéutica, intertextualidad..."

18 “Se puede enseñar a escribir?”.

"Se puede enseñar a redactar [bien], [...]. Pero escribir novelas es mucho más que redactar. Hay gente que domina muy bien el lenguaje, la sintaxis, y como novelistas no son gran cosa, es una cuestión de talento. Novelar es un secreto, una magia". Javier TOMEO, El País, 28-VIII-1999, pág. 10. 
El día que el profesor de Estructuras Argumentales pide a los alumnos que escriban un argumento, Lerma, aunque le parecía un plazo prematuro " $[\ldots]$ " para acceder a los alambicados secretos de la creación literaria." (pág. 111), decide ir "al café Trípoli, muy fecuentado por artistas, a la espera de que en aquel recinto se le adhiriera al pensamiento el fantasma errante de alguna idea fugada de la cabeza de algún escritor consagrado." (pág. 111). El "afanoso y perplejo buscador de un sólido argumento", como nos lo define el narrador, entabla allí una amigable charla con un anciano quien le hace algunas sugerencias al respecto, que Lerma tampoco entiende; pero, al día siguiente, puede entregar su ejercicio "centrado en el encuentro de un joven escritor con el Demonio, que le habia tentado para que abandonase su flamante carrera literaria, distinguida ya con la medalla abstracta que lucen en su amor propio todos aquellos que consiguen extraer de la nada un sólido argumento." (pág. 115).

En su "Cuento en la Escuela de Letras" Antonio Pereira detalla qué tipo de público la frecuenta: "acudimos los jubilados del Cuerpo diplomático, señoras de Madrid con mucho tiempo libre, niñas céntricas que se han cansado de picotear en la decoración y los idiomas" (pág. 217). Suele ser también práctica habitual, como complemento a las clases que se imparten, contar con la presencia de ilustres figuras que, sin más, aprovechan para leer sus propias "fabulaciones". El protagonista del relato nos da a conocer su experiencia al respecto. Después de leerles uno de sus relatos, el escritor invitado "se levantó de la mesa de conferenciante en nuestra escuela de pago y resumió sus consejos: "Estudien a ese Dale Carnegie, no se puede entrar mejor y más rápido en una historia." Deletreó el nombre y fue a escribirlo en la pizarra para que no hubiera duda: DALE CARNEGIE. Con lo cual, pasamos al cóctel." (pág. 219); así acaba el cuento que leemos. A buen entendedor...

Tampoco la crítica y quienes la ejercen salen incólumes de la mordacidad con que algunos autores arremeten contra ciertos tics del panorama literario actual. Podemos comprobarlo en el cuento de Jordi Llavina, "Sistemes de la Crítica Literària", cuyo narrador constata la peculiar destreza del protagonista "un escriptor ambidextre": "Amb l'esquerra [...] componia poemes llargs en vers lliure i bravada romàntica [...]. Amb la dreta, signava columnes periodístiques amb molta càrrega política, redactava feixugues novel.les històriques i firmava papers oficials i dedicatòries" (pág. 167). A raíz del percance casero que le obliga a llevar escayolada la mano derecha durante dos meses y medio, los críticos detectan un cambio en su forma de escribir que atribuyen "a factors de reiteració [...] que havien menat la seva obra narrativa i periodística a l'atzucat d'un expressionisme llòbrec; a un eixarreïment dels referents $i$ dels valors $i$ a un encarcarament insostenible de la seva planificació retòrica". (pág. 168). Palabrería hueca de supuestos especialistas de quienes el narrador se permite discrepar ' $[$.... si de cas, se m'acut, amb tota la humilitat, que es podria fer a aquesta Crítica Rigorosa $i$ Oficial el retret de no haver-se adonat que el parèntesi curt però significatiu que quedaria imprès amb lletres de motllo als repertoris d'Història de la Litertura Universal com una etapa incòmoda però enriquidora de l'obra multifacètica del nostre autor 
havia coincidit, punt per punt, amb el braç enguixat que tan emprenyador se li va fer al pacient." (pág. 169).

El esnobismo, el seguimiento de las modas para figurar en el espectro literario actual, el endiosamiento en que caen determinados autores que consiguen encumbrarse de la noche a la mañana, nada escapa a la sagaz percepción y/o punzante sátira, no exenta de connotaciones críticas, de los propios escritores. Podríamos multiplicar los ejemplos, pero nos centraremos en un solo aspecto. Valgan como muestra representativa dos relatos, que abordan con humor ese culto actual a la mínima expresión literaria. "El conte curt sóc jo. Enchanté" (pág. 23), son las últimas palabras que puede proferir "l'inspirador de l'"estètica de la reducció" (i també l'encunyador del terme)"'(pág. 23), al serle presentado al narrador, concretamente, "en un congrés d'escriptors de contes curts", antes de caer fulminado por un infarto. ¿Cómo no va a sentirse orgulloso el protagonista del cuento de Jordi Llavina, "Congrés d'Escriptors", de pasar "a la Història de la Literatura com l'autor a qui l'escriptor de contes curts més important de la nostra època va adreçar la darrera frase (una frase que, dos anys després, en un dels congressos anuals dedicats a la seva memòria, experts $i$ hereus de l'autor van decidir que fóra la que honraria la seva tomba, gravada com a colofó de tota una vida i tota una obra en la seva làpida mortuòria. Amb l'enchanté i tot)"? (pág. 24).

En "Daná Literae", uno de los cuentos incluidos en la antología de relatos hiperbreves Quince líneas, que recoge los mejores presentados a concurso, nuevamente se somete a burla la propia práctica del minimalismo. Antonio García, aquejado de una enfermedad "considerada recientemente como profesional y altamente contagiosa [...], [que] consiste en el desmoronamiento sintáctico progresivo del escritor a partir de determinada línea, en mi caso la decimotercera del texto que nos ocupa" (pág. 55), y alegando que ésta le impide escribir coherentemente más de doce líneas, solicita que se acorte el número de líneas en las próximas convocatorias del concurso. No es una casualidad, pues, que a partir de la línea trece, hasta llegar a la quince, el relato que leemos resulte totalmente incongruente.

"[...] se sentía novelista, un autor destinado a empresas de mayor envergadura que la simple redacción de textos breves, a menudo tan efímeros como la celeridad con que son leídos y luego olvidados. [...]. Los relatos siempre serían novelas cojitas, mutiladas" (pág. 14).

"La verdad es que eran relatos lo único que muy de tanto en tanto le requerian de ciertos círculos literarios españoles. Con frecuencia para ser publicados en oscuras y multitudinarias antologías junto a los de un pelotón de perfectos desconocidos." ("Crítica de la Razón Impura", pág. 15).

Ni son "novelas cojitas y mutiladas", como los considera el escritor-fictivo del cuento de Javier García Sánchez, ni en las numerosas antologías del 
género que se publican figuran sólo "un pelotón de perfectos desconocidos". Bien al contrario, el cuento parece llamado a ser el género del siglo XXI. Hay críticos y escritores que lo defienden con contundencia: "En un mundo cada vez más acelerado el arte ha de refugiarse en formas rápidas, concisas, que transmitan de forma inmediata, sin pérdida de tiempo, aquello que el artista tiene que decir"19.

"La señal de que el milenio está por concluir tal vez sea la frecuencia con que nos interrogamos sobre la suerte de la literatura y del libro en la era tecnológica llamada postindustrial" sostiene Italo Calvino en Seis propuestas para el próximo milenio ${ }^{20}$. ¿Explicaría esto el interés reiterado, según constatamos a través de los cuentos seleccionados, por hacer literatura de (sobre) la literatura, sin dejar al margen aspectos de naturaleza extraliteraria indefectiblemente vinculados a ella?

No nos hemos propuesto en ningún momento responder a la pregunta ni polemizar al respecto, sino dejar constancia de cómo el cuento -tanto en la literatura castellana como en la catalana - aborda desde muy diversas perspectivas estos aspectos tan candentes, tras poner de manifiesto la importancia que reviste actualmente esta forma narrativa breve. Sólo nos queda añadir que nos sumamos, por nuestra parte, a cuantos valedores de prestigio auguran un porvenir halagüeño al género con la mirada puesta en el siglo XXI; no en vano reúne dos de los valores - "levedad" y "rapidez" - que el testamento literario de Calvino considera primordiales para el próximo milenio.

\section{BIBLIOGRAFÍA}

AA.VV., El cuento en España 1975-1990, Lucanor, n. ${ }^{\circ}$ 6, septiembre 1991.

AA.VV., Quince líneas. Relatos hiperbreves, Barcelona, Tusquets, 1996.

ANGLADA, M. ${ }^{a}$ Àngels, "L'estilogràfica", La daurada parmèlia i altres contes, Barcelona, Ed. Columna, 1991, págs. 55-60.

Benítez Reyes, Felipe, "El alumno", Un mundo peligroso, Valencia, Pre-Textos, 1994, págs. 109-115.

Cerezales, Agustín, "Diálogo de sordos", Escaleras en el limbo, Barcelona, Ed. Lumen, 1991, págs. 165-169.

DeL Río, Isabel, "Nadie", Los cuentos que cuentan (ed. J.A. Masoliver y F. Valls), Barcelona, Anagrama, 1998, págs. 237-243.

DíAz-MAS, Paloma, "El señor Link vista a un autor", Nuestro milenio, Barcelona, Anagrama, 1987, págs. 49-54.

\footnotetext{
${ }^{19}$ Marina MAYORAL, Cuento español contemporáneo, pág. 136.

${ }^{20}$ ITAlo Calvino, Seis propuestas para el próximo milenio, Madrid, Eds. Siruela, 1998, pág. 17.
} 
DíEz, Luis Mateo, "Los temores ocultos", Antología del cuento literario (ed. M. Díez Rodríguez), Madrid, Alhambra, 1985, 2. ${ }^{a}$ ed., págs. 76-80.

Dracs, Ofèlia, "La por del caixer davant la pistola", Negra $i$ consentida, Barcelona, Ed. Laia, 1983, págs. 7-21.

_ "La matèria dels somnis", Essa efa, Barcelona, Ed. Laia, 1985, págs. 9-28.

FERNÁNDEZ CUBAS, Cristina, "En el hemisferio sur", Mi hermana Elba y los altillos de Brumal, Barcelona, Tusquets, 1988, págs. 131-153.

FERnÁndez Roces, Luis, "Relato de noche", Cuento español de Posguerra, (ed. Medardo Fraile), Madrid, Cátedra, 1994 (5.a ed.), págs. 318-329.

FREIXAS, Laura, “La intérprete”, Lucanor, n. ${ }^{12}$, diciembre 1994, págs. 24-32.

- "Final absurdo", El asesino en la muñeca, Barcelona, Ed. Anagrama, 1988, págs. 49-61.

García SÁNChez, Javier, "Crítica de la Razón Impura", Crítica de la Razón Impura, Barcelona, Edhasa, 1991, págs. 9-62.

LlamaZares, Julio, "La novela incorrupta", En mitad de ninguna parte, Madrid, Ollero \& Ramos Edts., 1995, págs. 57-71.

LlavinA, Jordi, "Congrés d'Escriptors", "Sistemes de la Crítica Literària", La mà tallada, Barcelona, Eds. Proa, 1999, págs. 23-24; 167-169.

MARTínez dE PISÓN, Ignacio, "La muerte mientras tanto", Cuentos de terror, Barcelona, Ed.Grijalbo, 1989, págs. 61-77.

MERINo, José M.a, "El viajero perdido", El viajero perdido, Madrid, Alfaguara, 1990, págs. 9-27.

Millás, Juan José, “El pequeño cadáver de R.J.”, Primavera de luto y otros relatos, Barcelona, Eds. Destino, 1992, págs. 9-25.

Moncada, Jesús, "L’assassinat del Roger Ackroyd”, El cafè de la Granota, Barcelona, Eds. de la Magrana, 1988, 2. ${ }^{\text {a }}$ ed., págs. 69-75.

Monzó, Quim, "Thomson, Braun, Corberó, Philishave...”, ... Olivetti, Moulinex, Chaffoteaux et Maury, Barcelona, Quaderns Crema, 1983, págs. 21-31.

- "El conte", El perquè de tot plegat, Barcelona, Quaderns Crema, 1993, págs. 167-169.

— "La literatura", Guadalajara, Barcelona, Quaderns Crema, 1996, págs. 95-99.

MORET, Xavier, "Es gasten els llapis quan se'n va la llum?", Estimats pares, Barcelona, Ed. Planeta, 1996, págs. 147-160.

Muñoz Molina, Antonio, "Borrador de una historia", Nada del otro mundo, Madrid, Espasa-Calpe, 1993, págs. 193-200.

PÀMIES, Sergi, "Deu paràgrafs", La gran novel.la sobre Barcelona, Barcelona, Quaderns Crema, 1997, págs. 59-69.

Pereira, Antonio, “Coleccionistas de historias", "Cuento en la Escuela de Letras", "Una semana y un día”, Me gusta contar (Selección personal de relatos), Barcelona, Taller de Mario Muchnik, 1999, págs. 154-155; 217-219; 220-224. 
Pujol, Carlos, "La ficción", Holmes, Watson y Compañía, Barcelona, V.I.T.R.O.L, $1994, \mathrm{~s} / \mathrm{p}$.

RIERA, Carme, "Això no és un conte", Contra l'amor en companyia i altres relats, Barcelona, Eds. Destino, 1991, págs. 163-169.

SÁnCHEZ-OrTiz, Emilio, "Hoy, como todos los días", "Un apunte", Cuentos, historias y otros deseos insatisfechos, Madrid, Alfaguara, 1997, págs. 143-154; 191-197.

SERRA, Màrius, "Transcripció", "Incert so", "Documentació", "Postil-la", La vida nor mal, Barcelona, Eds. Proa, 1998, págs. 13-25; 29-49; 117-138; 141-154.

SOlSONA, Ramon, "La inspiració del novel-lista", "Una història lamentable", Llibreta de vacances, Barcelona, Quaderns Crema, 1991, págs. 107-114; 137-155.

SuÁrEz, Gonzalo, "Interludio", El asesino triste, Madrid, Alfaguara, 1994, págs. 125. 126.

SUBIRANA, Jaume, "La pantalla", AA.VV, El triangle de les set punxes. Històries d'horror, Barcelona, Ed. Tanagra, 1990, págs. 167-186.

VÁzquez Montalbán, Manuel, "El alevoso asesinato de Ágatha Christie", Pigmalión y otros relatos, Barcelona, Seix Barral, 1987, págs. 103-108.

VIADER, Jordi, "L'autor plagiat", Ni una gota de sang xarnega, Barcelona, Eds.62, 1986, págs. 11-17.

ZARRALUKI, Pedro, "La inspiración caótica", Retrato de familia con catástrofe, Barcelona, Ed. Anagrama, 1989, págs. 13-24.

ZúNIIGA, Juan Eduardo, "La esposa", "La venganza", Misterios de las noches y los días, Madrid, Alfaguara, 1992, págs. 47-54; 135-139. 